\title{
Construction corrupts: empirical evidence from a panel of 42 countries
}

\section{Andreas P. Kyriacou ${ }^{1 *} \cdot$ Leonel Muinelo-Gallo ${ }^{2} \cdot$ Oriol Roca-Sagalés $^{3}$}

${ }^{1}$ Departament d'Economia, Universitat de Girona, Campus de Montilivi, 17071, Girona, Spain (e-mail: andreas.kyriacou@udg.edu; telephone: +34 97241 8716).

* Corresponding author.

${ }^{2}$ Instituto de Economía de la Universidad de la República, Joaquín Requena 1375, Código Postal 11200, Montevideo, Uruguay (email: 1muinelo@iecon.ccee.edu.uy).

${ }^{3}$ Departament d'Economia Aplicada, Universitat Autònoma de Barcelona, Edifici B, Bellaterra 08193, Barcelona, Spain (e-mail: oriol.roca@uab.cat).

\begin{abstract}
The construction sector, whether privately or publicly financed, is characterized by potentially large rents and government intervention making it vulnerable to corruption. Consistent with this, both case-study and survey evidence has been provided highlighting the problem of malfeasance in this sector. In this article, we test the proposition that a bigger construction sector is likely to be inimical to clean government based on a panel of 42 countries over the period 1995 to 2011 . We control for a range of potentially confounding variables and the expectation that corrupt public officials may favor the development of this sector because it increases the volume of rents available to them. Our empirical evidence shows that a larger construction sector will tend to increase perceptions of the extent to which public power is exercised for private gain.
\end{abstract}

\section{JEL Classification: D73 $\cdot$ L74}

Key words: Corruption · Economic Sectors · Construction Sector · Empirical

Estimates $\cdot$ Reverse Causality

Article published in Public Choice 65(1): 123-145 (2015). 


\section{Introduction}

Corruption or the abuse of public office for public gain is bad for society. Among its many ills, economists have reported that corruption reduces economic growth (Knack and Keefer 1995; Mauro 1997; Tanzi and Davoodi 2001; Pellegrini and Gerlagh 2004), increases income and educational inequalities (Gupta et al. 2002), reduces spending on health and education (Mauro 1998; Gupta, Davoodi and Tiongson 2001) and enlarges the underground economy, thus reducing government revenues (Johnson et al. 1998).

Because of the negative impact of corruption on desirable socio-economic objectives, social scientists have attempted to identify the factors that drive malfeasance. These include economic conditions, such as the level of economic development (Treisman 2000), income inequalities (You and Khagram 2005), political factors, such as the level of democracy (Bäck and Hadenius 2008) and electoral rules (Persson et al. 2003), and cultural factors (Fisman and Miguel 2007) that have been linked to religious affiliations (La Porta et al. 1999).

Several authors have identified the pernicious effect of natural resources on governance. The natural resource sector is one characterized by state regulation and large rents and profits that result in part from the absence of competitive market conditions (Ades and Di Tella 1999). This combination of rents and regulation creates opportunities for corrupt behavior by public officials. In line with this, the empirical evidence to date has tended to confirm the links between natural resource endowments and corruption (see, for example, Aslaksen 2009 and Busse and Gröning 2013). Moreover, scholars have identified the existence of a "resource curse", such that natural resources, by increasing corruption, tend to reduce rather than increase economic growth (Leite and Weidmann 2002; Isham et al. 2005; Sala-i-Martin and Subramanian 2013). 
Inspired by this literature, in this article we turn to another sector of the economy - the construction sector - which is similarly characterized by relatively high value investments and significant government interactions, thus providing opportunities for rent creation and extraction by corrupt public officials (Hardoon and Heinrich 2011). The construction market in most countries is split between a competitive segment composed of large number of small contractors and an oligopolistic, often cartelized tranche, made up of a limited number of firms handling the larger construction projects (OECD 2008; Kenny 2009). The sector includes both publicly and privately financed construction projects and government intervention can take several forms, the most obvious being public tenders to undertake public investment projects and local government zoning or town planning decisions that affect the construction of private housing.

In line with empirical work exploring the impact of natural resources on governance, we posit that countries with larger construction sectors, both in terms of volume and as a percentage of Gross Value Added (GVA), ${ }^{1}$ are likely to suffer from more corruption. We explore this by way of an unbalanced panel of 42 mostly middle and high income countries over the period 1995 to 2011 . We find that a more economically important construction sector tends to increase perceptions of corruption even after controlling for a range of potentially confounding variables and the real possibility that corrupt officials may promote the development of the construction sector since it increases the resources appropriable by them.

\footnotetext{
${ }^{1}$ GVA measures the contribution to the economy of each individual industry or sector by estimating the value of an output (goods or services) less the value of inputs used in that output's production process. GVA relates to Gross Domestic Product (GDP) as follows: GDP $=$ GVA + taxes on products - subsidies on products.
} 
This article is structured as follows. In the next section we develop the reasoning behind the expectation that a larger construction sector will tend to increase corruption, and review current evidence of corruption in that sector. We then present how we measure our key variables and explain our empirical approach. Finally, we report and discuss our main empirical findings before concluding the article.

\section{Construction and corruption: theory and existing evidence}

According to one estimate, corruption in the construction industry accounts for an estimated $\$ 340$ billion of worldwide construction costs each year, representing $10 \%$ of construction's global market value (ASCE 2004). Corruption in the industry leads to cost overruns, poor quality construction, inefficient project selection and deficient maintenance (Kenny 2006, 2009), and has been linked to earthquake-related injuries and deaths caused by sub-standard buildings and infrastructure (Escaleras et al. 2007). Corruption in public construction projects is particularly damaging for developing countries with important infrastructural deficiencies and scarce resources (Hardoon and Heinrich 2011).

The industrial organization of the construction industry across countries speaks to the availability of large rents that can fuel corruption. National construction sectors are characterized mainly by the presence of a limited number of big firms having the capacity to undertake large construction projects. Perhaps not surprisingly then, competition in the construction industry tends to be imperfect, with anti-competitive practices occurring frequently, mostly in the guise of collusive agreements between firms. In this respect, the OECD (2008) documents a series of high-profile examples of construction cartels brought to light during 1997-2007 in several countries, including, Turkey, South Korea, Japan, the United Kingdom, the Netherlands and Germany. This 
collusion takes several forms, such as bid rigging, sales restrictions, price fixing and market allocation deals.

A range of mostly qualitative country case studies have considered the nature of corruption in the construction industry (see Le et al. 2014 for a survey). Corruption can occur at any stage of a construction project, from planning and design, bidding and construction to operation and maintenance. It can manifest itself in many related forms, including bribing public officials involved in key decisions affecting private and public construction projects, bid rigging by public administrators to ensure that a favored tenderor wins the project, or even the extortion of construction companies to extract bribes. And several factors have been identified as contributing towards corruption in the construction sector, including ethical preferences related to culture, ineffective legal systems, insufficient transparency in tenders, asymmetric information among tenderees, difficulties in benchmarking for cost and time given the uniqueness of many construction projects, and the practice of subcontracting, which makes the tracing of payments and the diffusion of "best practice" standards more complex.

From a theoretical perspective, the combination of government intervention and large rents flowing from imperfect competition will tend to increase corruption. Why this may be so has been uncovered in work studying the impact of the natural resources on corruption. Leite and Weidman (2002) argue that the availability of large rents in the resources sector can lead private agents to compete for them by paying bribes to public officials in exchange for administrative approvals of their investment projects. From a different perspective, assuming that bureaucrats vary as to the values they assign to honest dealings, and for a given bureaucratic wage scale, the large rents characteristic of the natural resource sector increase the incentive of bureaucrats who regulate the sector to engage in malfeasant behavior (Ades and Di Tella 1999). Finally, corruption may 
emerge from the interaction of private and public agents in the context of rents that may accrue to the public sector either directly, as owners of natural resources, or indirectly, through taxation of private sector owners of them.

Although this discussion is framed in terms of corruption, we must be clear that our analysis falls squarely within the rent-seeking literature. Corruption involving bribes to politicians and bureaucrats is a type of rent-seeking in as much as the latter has been defined as the employment of scarce resources to obtain an artificially created transfer through favorable public sector decisions (Tullock 1967; Buchanan 1980; Tollison 1982). But, whereas the traditional rent-seeking literature models politicians as passively responding to rent-seeking activities by private-sector agents, in the context of corruption, public sector agents may have a private interest in responding favorably to rent-seekers or even take the initiative in creating the rents through policy, so as to pocket their share (McChesney 1997; Lambsdorff 2002). From this perspective, the potential of large rents from public policies is likely to lead to more corruption both because of the rent-seeking efforts of private-sector agents and because of the responsiveness or initiative of corrupt public sector officials. ${ }^{2}$

\footnotetext{
${ }^{2}$ Corruption through bribes is not the same as lobbying, another form of rent-seeking (Lambsdorff 2002; Svensson 2005). Lobby groups achieve policy changes that are favorable to other firms in their sector while the benefits of bribing tend to accrue to the bribing firm. Moreover, decisions in response to lobbying are likely to be made by governments weighing the benefits of additional income against the political costs of benefiting particular groups, while those in response to bribes will tend to be made by individual public officials who consider their private costs and benefits. Finally, because bribes are illegal while lobbying is not necessarily so, the former are more likely to remain hidden.
} 
This discussion sheds light on how the construction sector may facilitate corruption. The limited competition in the sector together with the major role of government as clients, regulators, and owners of construction companies (Sohail and Cavill 2008; Kenny 2009) describes a setting in which, on the demand side, private agents have an incentive to bribe public officials in exchange for favorable decisions and, on the supply side, public officials have an incentive to favor companies in exchange for bribes, leading to the expectation that countries wherein the construction sector is relatively important will tend to experience more corruption.

The positive association between the size of the construction sector and corruption (both that involving public officials and that between private agents) has been picked up by several surveys. Since 1999, Transparency International's Bribe Payer's Index (BPI) has reported company executives' perceptions of the likelihood that companies from 28 leading countries (the G-20 plus eight) win business abroad by paying bribes (Hardoon and Heinrich 2011). The executives surveyed by Transparency International consider that companies doing business in the public works and construction sectors are the ones most likely to bribe to obtain contracts. Moreover, the BPI finds that countries in which companies are more likely to pay bribes abroad are also those with higher levels of perceived corruption at home. The positive association between the construction sector and corruption abroad likewise has been reported by the OECD based on actual corruption cases brought to light (OECD 2014). Of the 427 cases of corruption of public officials between 1999 and 2014, the OECD found that companies from the extractive industries were most likely to engage in corrupt practices, followed closely by those in the construction, transportation and storage sectors.

Despite the existence of numerous country case studies and survey evidence indicating the possible positive effects of the construction industry on corruption, to our 
knowledge this relationship has not received any systematic empirical attention. At most, previous work has reported regressions of bribes paid to obtain construction permits on the log of GDP per capita, finding a negative relationship in a cross-section of 29 countries (Kenny 2009). We propose, for the first time, to analyze econometrically the impact of the construction sector on corruption. To do so, we rely on a panel of 42 countries over a 17-year period. Our empirical approach controls for the confounding influence of a range of variables. Moreover, we make some effort to account for the possibility of reverse causality. In this respect, several authors have examined the extent to which corruption can affect the development of the construction sector and, more generally, the composition of public expenditures. The point of departure of this line of work is Shleifer and Vishny (1993), who argue that corrupt governments are likely to favor infrastructure and defense projects where corruption opportunities are abundant (compared to spending on say, education and health). The empirical evidence largely is supportive of this conjecture since corrupt countries tend to overinvest in public infrastructure, which, moreover, tends to be of lower quality (Tanzi and Davoodi 1997), to spend less on infrastructure maintenance than on new capital projects, spend more on defense (Gupta, de Mello and Sharan 2001) and less on education (Mauro 1997, 1998) and social welfare programs (Hessami 2014). Drawing on evidence across US states, Liu and Mikesell (2014) report that corruption increases spending on public construction projects and reduces spending on education and health. This work is important in its own right, but for our purposes here, it alerts us to the possibility that the direction of causality between corruption and construction runs both ways. We describe how we deal with this issue in the next section. 


\section{Data and empirical method}

Our measure of the construction sector's size is the ratio of gross value added (GVA) of that sector to total GVA and comes from the World Input-Output Database (WIOD) Socio-economic Accounts (SEA), a source that provides industry-level time series for 40 countries from 1995 to 2011. Specifically, the WIOD-SEA reports information on gross value added, by country, disaggregated across 35 industries, including the construction industry. ${ }^{3}$ We expand our sample using data from the OECD's Database for Structural Analysis (STAN). Our final sample comprises 27 EU countries (Croatia is not included), three other European countries (Iceland, Norway and Switzerland), Russia, Turkey and four Asian countries (India, Indonesia, South Korea and Japan), four American countries (Brazil, Canada, Mexico and the United States) plus Australia and New Zealand (see appendix A for the list of countries and appendix B for data definitions and sources).

Although the WIOD-SEA is silent on the subcomponents of the construction variable, the European Commission's Annual Macro-Economic Database (AMECO) provides data on the composition of the construction sector for most of the OECD countries that we study in this article. It shows that between 1995 and 2011, construction of dwellings accounted for almost $40 \%$ of the sector, while non-residential construction and civil engineering comprised the remainder. As such, our measure of construction could be divided into two large subsets: one basically financed by the private sector (dwellings) and another mostly financed by the public purse.

\footnotetext{
${ }^{3}$ Timmer et al. (2015) provides an overview of the contents, sources and methods used in compiling the World Input-Output Database and surveys recent work employing this source.
} 
We, moreover, propose to measure the importance of construction by multiplying the previous variable by country GDP (in logs). The reason for this is to take into account not just the weight or relative size of the sector in the economy, but also to control for the amounts of resources involved. Doing so can capture the possibility that during an economic expansion (contraction), the weight of construction in the economy may remain stable, but the amount of resources and thus rents generated by the sector may experience a significant increase (decrease), something that may have a bearing on corruption. ${ }^{4}$ For instance, Slovenia (1997), Portugal (1998), the Netherlands (1999) and Sweden (2000) grew by almost 5\% (during the specified years), while the ratio of construction to total GVA remained very stable. Alternatively, the Baltic countries experienced a very severe economic crisis in 2009 (with GDP reductions exceeding $10 \%$ ), but at the same time the share of construction in GVA remained constant. Consequently, just considering the relative size of the construction sector would not necessarily capture the quantity of resources employed in it, something that is likely to affect the extent of corruption in that sector.

To measure corruption, we rely on the World Governance Indicators (WGI). Specifically, we employ the Control of Corruption measure from that source, which measures "perceptions of the extent to which public power is exercised for private gain, including both petty and grand forms of corruption, as well as 'capture' of the state by elites and private interests" (Kaufmann et al. 2010, p. 4). This indicator has been widely used in research empirically calibrating the causes and consequences of corruption. It varies between -2.5 and 2.5: larger values reflect less perceived corruption. In our

\footnotetext{
${ }^{4}$ In this relation, Jiménez (2009) describes how the building boom in Spain fuelled political corruption there.
} 
sample of countries, perceived corruption is greatest in Russia, Indonesia and India, while it is lowest in Scandinavia and New Zealand (see appendix C for the summary statistics). As a robustness check, we also employ an alternative measure of perceived corruption, namely that provided by the Political Risk Services group in the context of their International Country Risk Guide (ICRG).

The use of perception-based corruption data has been criticized because they do not correlate well with measures of reported corruption experience, typically drawn from survey questions asking individuals if they have paid a bribe (see, most recently, Heywood 2015 and Treisman 2015, although Charron 2015 presents evidence to the contrary). But data on reported bribes paid may also be biased insofar as "questions are politically sensitive, personally embarrassing or could lead to criminal sanctions", thus leading those surveyed to lie or underreport bribery incidents or, typically, not to respond at all to these type of questions (Jensen and Rahman 2015, p. 154; see also Treisman 2015). Notable cross-country sources of reported bribery are the United Nations International Crime Victims Survey, Transparency International's Global Corruption Barometer and the World Bank's Enterprise Surveys. The limited overlap between the available construction and bribery data does not allow us to rigorously test the robustness of our empirical findings using the latter. This said, with the data at hand, the simple correlation between the Control of Corruption measure and reported bribes from the Global Corruption Barometer is -0.702 ( $p$-value of 0 ), indicating that the perceptions-based indicator we employ may be a reasonable proxy for reported corruption.

As a first step in examining empirically the relationship between the construction sector and corruption, we plot the Control of Corruption measure against our two construction sector indicators. To simplify the presentation, we use average values for each variable 
over the sample period (1995-2011). The graphs are suggestive of a negative association between Control of Corruption and the construction sector's relative size or, in other words, a larger sector is associated with more corruption. Figure 1 shows that the construction sector is relatively small in countries like Malta, New Zealand, Hungary and Norway, while it accounts for a larger portion of gross value added in Spain, Iceland, Cyprus and South Korea. A slightly different picture emerges from Figure 2 that plots the corruption measure against the indicator aimed at capturing the volume of resources employed in the construction sector. Now Spain, South Korea, Japan and India have larger construction sectors. The US construction sector also looks larger from this perspective. While the two figures are suggestive of a negative association between clean government and construction activity, they are of course silent on both the counfounding influence of other factors as well as the direction of causality. In what remains in this section we explain how we address those two important concerns.

\section{Figures 1 and 2 about here}

We estimate the following model:

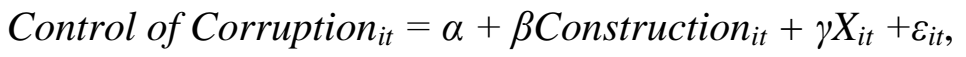

where $i$ refers to countries and $t$ to years, $\alpha$ is a constant, $X_{\mathrm{it}}$ is the vector of control variables and $\varepsilon_{\mathrm{it}}$ is the error term. Given our previous discussion we expect $\beta<0$. Since we have substantially more cross-section units than time periods, we follow Beck and Katz (1995) and estimate the model using OLS with panel corrected standard errors (PCSE) employing cross-section clustering or a covariance structure that computes standard errors that are robust to heteroscedasticity and serial correlation between the residuals for a given cross-section (Period SUR). Because of the limited within-country variation in the Control of Corruption measure in our sample (see appendix C), we do 
not apply cross-section fixed effects (see Baltagi 2013). Alternatively, we do introduce period fixed effects to account for the influence of unknown or unobservable time varying factors affecting all our cross-section units.

Our set of control variables is chosen so as to minimize omitted variable bias. In particular, we control for the logarithm of real GDP per capita, a country's population (in $\log$ ), public sector size, the openness of the economy, the importance of the oil and mining sectors (all as percentages of GDP), a measure of inter-personal income inequalities (a Gini index based on disposable income), the extent to which local governments have fiscal and political autonomy, and legal origins.

Accounting for the level of development allows us to control for the possibility that the relative importance of different economic sectors may vary with income (Imbs and Wacziarg 2003). Moreover, wealthier countries may be able to afford better quality public institutions (Islam and Montenegro 2002). We control for population since larger countries may be more difficult to govern (Treisman 2002), or may enjoy economies of scale in anti-corruption measures (Knack and Azfar 2003). The evolution of population over time is also likely to influence positively the demand for private and public construction. The need to control for the size of the public sector takes account of the fact that a larger public sector offers more opportunities for rent creation and, thus, facilitates corruption (Tanzi 1998). The resources available to the state likely determines its capacity for undertaking public construction projects.

Given our previous discussion, we also account for the importance of natural resources in a country's gross domestic product since this determines the availability of rents potentially captured by corrupt officials. The availability of rents also depends on the openness of the economy to trade, since competition from foreign firms will tend to 
reduce the rents enjoyed by domestic firms and, hence, the returns to corruption (Ades and di Tella 1999). Controls for the natural resource base and country openness also are warranted because both are likely to affect the sectoral specialization of the economy and thus, the relative size of the construction sector.

Because inter-personal income inequalities have been identified as potential determinants of corruption we also control for them (You and Khagram 2005; Uslaner 2010). Income inequalities may, moreover, influence the size of the construction sector either because they affect the capacity of individuals to purchase housing in the private sector or because they affect the demand for public services, which may imply public construction. We moreover control for the degree of fiscal and political autonomy enjoyed by local governments (Ivanyna and Shah 2014). Previous work has reported that greater dependence on one's own fiscal resources tends to reduce corruption because inter-jurisdictional competition for tax base disciplines subnational governments, while the election rather than appointment of local politicians has been linked to corruption, possibly because the proximity of public officials increases the likelihood of their capture by special interests (Kyriacou and Roca-Sagalés 2011a, 2011b). Controlling for local government autonomy is also warranted by the fact that local government decisions - for example the zoning of land as subject to building or not and the concession of building permits - affect the construction of new housing (see, for example, Wollman 2008 and Jimenez 2009).

Finally, we control for legal origins since scholars have argued that the depth and scope of state intervention - and thus possibilities for corruption - will tend to be greatest in countries with a Soviet legal tradition, lower in ones with a tradition of civil law (represented by the French, German and Scandinavian civil codes) and lowest in countries with common law systems (La Porta el al. 1999). Legal origins have also been 
linked to the regulation of entry of new firms and from there to the size of unofficial economies (Djankov et al. 2002). To the extent that either of these variables may affect the relationship between corruption and the construction sector, legal origin helps us to control for their confounding effect. ${ }^{5}$

A major concern when trying to identify the relationship between construction and corruption is the possibility of reverse causality. While the construction sector may facilitate corruption, it could also be the case that officials in more corrupt countries may adopt policies favoring the construction sector to the detriment of other sectors that do not provide similar opportunities for appropriating rents. Not accounting for this feedback effect is likely to generate point estimates of the impact of construction on corruption that are biased downward (since more effective control of corruption is likely to be associated with a smaller construction sector).

To deal with this issue we resort to two-stage least squares (TSLS) estimation wherein we instrument our measures of the construction industry with the percentage of population between 25 and 49 years of age and a dummy variable that takes the value of 1 in the presence of national elections and zero otherwise. The demographic variable helps us account for the construction of private dwellings because individuals within this age range are more likely to demand housing, while those below this range may still be living with their parents or renting, and those above this age group may have already bought a house. ${ }^{6}$ Alternatively, the national elections dummy is useful in capturing

\footnotetext{
${ }^{5}$ In the results section below we also report regressions that control for the importance of the shadow economy based on data from Schneider et al. (2010).

${ }^{6}$ See, Jafee et al. (1979), Mankiw and Weil (1989) and Lindh and Malberg (2008) for empirical evidence linking age cohorts to private housing demand.
} 
construction projects financed by the public sector on the assumption that during election periods, governments will tend to over-spend on infrastructure, which is a visible and discretionary component of public spending (Tanzi and Davoodi 1997). ${ }^{7} \mathrm{We}$ are careful to exclude early or snap elections when constructing the elections dummy to reduce the possibility of corruption affecting this variable. As additional robustness checks, we also employ lagged values of the construction measures as instruments - a strategy that is supported by the existence of fairly high within-country variability in these measures (see Appendix C).

\section{Empirical results}

Table 1 presents a first set of regressions of Control of Corruption on the measures of the construction sector and the control variables. Columns 1 to 3 employ the share of construction in GVA, while the last three columns show the results when entering the alternative measure of the construction sector that accounts for the volume of resources. The estimated impact of the control variables is in line with that found in previous studies. Focusing on the statistically significant coefficients, the results indicate that the level of income and the degree of fiscal autonomy of municipal governments are positively associated with Control of Corruption, while clean government is negatively related to the political autonomy of local governments, the relative importance of natural resources and French and Soviet legal origins (compared to having a British common law tradition). The results also indicate that a larger population tends to be associated with more corruption, lending some support to the suggestion that smaller

\footnotetext{
${ }^{7}$ Brender and Drazen (2005) have employed a similar approach to test for the presence of a political business cycle in the form of expansionary fiscal policy during election periods.
} 
countries may be better governed, although this finding is not robust across all specifications.

\section{Table 1 about here}

The results in Table 1 indicate that construction is negatively associated with Control of Corruption at statistically significant levels. Regressions 1 and 4 report OLS estimates and the remaining regressions are TSLS. Compared to the OLS regressions, employing TSLS tends to increase both the estimated impact and statistical significance of construction on corruption. This is consistent with the presence of reverse causality, something that, recall, should reduce the OLS point estimates. In panel B of Table 1 we, moreover, report the first stage regressions of the TSLS estimates. The t-statitstics of the instruments employed - the age cohort and the national elections dummy (regression 2 and 5) or the lagged value of the construction indicator (regressions 3 and 6) - suggest that the instruments are valid. This is confirmed by the F-statistics of the first-stage regressions that are always above the required critical values (see Staiger and Stock 1997 and Stock and Yogo 2005).

The estimated impact of construction on corruption is economically significant. Focusing on the results reported in the second column of Table 1, a one-standard deviation increase in construction as a share of GVA, reduces the Control of Corruption measure by 0.280 points or around $29 \%$ of a standard deviation in the Control of Corruption index. By way of illustration, consider South Korea and Belgium. Focusing on average values over the sample period, Korea's and Belgium's construction sectors represent, respectively, $7.828 \%$ and $5.037 \%$ of total GVA, while the corresponding Control of Corruption scores are 0.403 and 1.382 respectively. This implies that almost $29 \%$ of the corruption gap between South Korea and Belgium can be explained by the 
larger weight of the construction sector in the former country. Based on the same reasoning, our results suggest that $19 \%$ of the difference in the corruption scores between Poland and Germany may owe to the former's larger construction sector.

\section{Table 2 about here}

In Table 2 we further examine the issue of reverse causality. Specifically, we employ longer lags of the construction measures as instruments in TSLS regressions taking lags of up to four years. While doing so reduces the F-statitistic from the first-stage regression, this is still always well above the desirable critical value of 10 . Longer lags can help reduce the correlation between the instruments and the disturbances resulting from the existence of reverse causality and, indeed, the estimated impact of construction on corruption increases with the length of the lag, thereby supporting the view that corruption may also affect the size of the construction sector.

We pursue the robustness of our results further in Table 3 where, again, we employ TSLS. In columns 1 and 2 of this table, we replace the measures of fiscal and political decentralization with an alternative indicator proposed by Ivanyna and Shah (2014). In addition to incorporating information on the degree of fiscal and political autonomy enjoyed by local governments, this measure includes information on their administrative autonomy (the share of local government employment in general government employment and the extent to which local governments can choose human resources policy), and the security of local governments (as measured by the constitutional and legal restraints on their arbitrary dismissal by higher level governments). This alternative measure, called Decentralization Index, is not associated with corruption at statistically significant levels, which, perhaps, is to be expected since it incorporates the notions of fiscal and political autonomy that relate to corruption in opposite ways. More 
importantly for our purposes here, our substantive results remain unchanged: we continue to find that construction has a negative and statistically significant impact on Control of Corruption.

\section{Table 3 about here}

In columns 3 and 4 of the table we additionally control for the confounding influence of culture as captured by the size of different religions in a country. Several authors have related Protestantism to less corruption and Catholicism, Islam and the Eastern Orthodox tradition to more, perhaps because the latter three are more hierarchical and, as such, inculcate values that make people less likely to challenge public office holders (La Porta et al. 1999; Treisman 2000; North et al. 2013). Moreover, Guiso et al. (2003) report systematic differences between individuals from different religions across a range of economic attitudes on issues such as tax evasion, public versus private ownership, the importance of luck and chance versus hard work for success, the importance of thrift, and whether competition is good or harmful. These attitudes potentially could have some influence on both the demand and supply sides of the private and public construction markets, thus justifying the need to control for different types of religions in our estimates. As shown in the table, these variables do not have a statistically significant impact in our sample and the estimated impact of construction is robust to their introduction.

Regressions 5 and 6 report the results when controlling for the importance of shadow economies. As expected, a larger unofficial economy has a negative impact on perceptions of clean government. The impact of construction also continues to be negative and statistically significant. Columns 7 and 8 of Table 3 show the results when using an alternative measure of corruption from the ICRG. In our sample, this indicator 
varies between 1 and 6, and higher values reflect a lower risk of corruption. The use of this indicator as the dependent variable does not change our results. Finally, in columns 9 and 10 we report the results of employing five-year averages of the data. The significant reduction in the sample size acts as a further robustness check. Moreover, because our decentralization and legal origin indicators are constant over time, adopting this approach goes some way toward accounting for the possibility that our panel results are being driven by repeated entries. Finally, the use of five-year averages also helps control for the business cycle and, thus, to focus on the structural relationship between the main variables of interest. As can be seen, employing five-year averages does not change our substantive results. ${ }^{8}$

\section{Conclusion}

The construction industry is vital to national prosperity. The construction and maintenance of public infrastructure is an indispensable component of a productive economy. And the construction sector, both private and public, is important in its own right, accounting for a sizeable share of a country's output and employment. According to the European Commission (2013), the construction sector accounts for almost $10 \%$ of European Union GDP and 20 million direct jobs; similar figures are reported for OECD countries (OECD 2008). This may be one reason why policymakers aim to promote the development of this industry. A case in point is Construction 2020, an action plan adopted by the European Commission to promote the sector by way of more favorable investment conditions, human capital improvements, better resource efficiency, and the

\footnotetext{
${ }^{8} \mathrm{We}$ also check the robustness of our results to both the exclusion of any particular country from the sample and the omission of pairs of potential outliers (for example, Iceland-Spain and Indonesia-Russia). Our results are preserved and are available upon request.
} 
strengthening of both the internal market for construction and the globally competitive position of EU construction firms (European Commission 2014).

In this article we have argued that because the construction sector is characterized by potentially large rents and government intervention, it may contribute towards public sector malfeasance. Our empirical evidence, based on a sample of 42 countries over the 1995-2011 period and accounting for both the confounding effect of other variables and the possibility that corrupt officials may favor the development of the construction sector, provides robust support for the negative impact of construction on perceptions of the extent to which corruption is controled.

The analysis supports calls for adopting anti-corruption measures in this industry at the same time it recognizes that public officials in corrupt countries may tend to resist policies that lessen their access to rents. One set of measures that has been put forward aims at increasing transparency in the dealings of both construction firms and governments by, for example, empowering wistleblowers in both the private and public sectors through implementing appropriate policies and procedures (Sohail and Cavill 2008; Hardoon and Heinrich 2011). Another measure refers to the adoption of ethical codes and related training programs for construction industry professionals such as the Australian National Code of Practice of the Construction Industry (Le et al. 2014). Beyond the obvious policy of raising the legal penalties facing those convicted of corruption, others have suggested the adoption of a debarment system - already in force in the European Union - whereby companies or individuals who are found guilty of corruption are prevented from participating in future construction projects (Jong et al. 2009). Finally, to the extent that corruption in the construction industry is explained by imperfect competition, then promoting competition, especially in relation to bids for 
public sector construction projects, is clearly a desirable policy (see also Ades and Di Tella 1999 and Kenny 2009).

Our evidence is consistent with that reporting a deleterious effect on governance coming from another economic sector characterized by substantial rents and state involvement, namely the natural resource sector. That literature has, moreover, reported evidence of a resource curse whereby the abundance of natural resources has a negative impact on economic growth both directly because it crowds out other sectors (Sachs and Warner 1995), but also indirectly, through its negative effect on governance (Leite and Weidmann 2002; Bulte et al. 2005; Isham et al. 2005, Sala-i-Martin and Subramanian 2013). Our analysis is silent on the direct effect of the construction sector on growth

rates (see, for example, Wilhemsson and Wigren 2011), but it is suggestive of an indirect negative effect transmitted through corruption's harmful effect on governance. We leave it for future research efforts to fully explore this important issue.

\section{Acknowledgements}

This paper has benefited from comments by two anonymous referees and William F. Shughart II. Andreas Kyriacou and Oriol Roca-Sagalés would like to acknowledge financial support from project ECO2012-31081 (Ministerio de Educación y Ciencia) as well as 2014 SGR 239 and XREPP (Direcció General de Recerca). Leonel Muinelo would like to acknowledge financial support from project I+D 2012 (Comisión Sectorial de Investigación Científica - Universidad de la República - Uruguay). 


\begin{tabular}{cl} 
Country Code & Country \\
AUS & Australia \\
AUT & Austria \\
BEL & Belgium \\
BRA & Brasil \\
BGR & Bulgaria \\
CAN & Canada \\
CYP & Cyprus \\
CZE & Czech Republic \\
DNK & Denmark \\
EST & Estonia \\
FIN & Finland \\
FRA & France \\
DEU & Germany \\
GRC & Greece \\
HUN & Hungary \\
ISL & Iceland \\
IND & India \\
IDN & Indonesia \\
IRL & Ireland \\
ITA & Italy \\
JPN & Japan \\
KOR & Korea, Republic of \\
LVA & Latvia \\
LTU & Lithuania \\
LUX & Luxembourg \\
MLT & Malta \\
MEX & Mexico \\
NLD & Netherlands \\
NZL & New Zealand \\
NOR & Norway \\
POL & Poland \\
PRT & Portugal \\
ROU & Romania \\
RUS & Russia \\
SVK & Slovak Republic \\
SVN & Slovenia \\
ESP & Spain \\
SWE & Sweden \\
CHE & Switzerland \\
TUR & Turkey \\
GBR & United Kingdom \\
USA & United States \\
\hline &
\end{tabular}




\section{Appendix B: Data definitions and sources}

\begin{tabular}{|c|c|}
\hline Control of Corruption - WGI & $\begin{array}{l}\text { Assessment of corruption within the political system. Lower values imply a } \\
\text { higher level of corruption (World Governance Indicators, World Bank). }\end{array}$ \\
\hline Corruption - ICRG & $\begin{array}{l}\text { Assessment of corruption within the political system. Lower values imply a } \\
\text { higher level of corruption (International Country Risk Guide, Political Risk } \\
\text { Services Group). }\end{array}$ \\
\hline Construction & $\begin{array}{l}\text { Gross value added of the construction sector divided by total gross value added } \\
\text { (World Input-Output Database Socio-economic Accounts (WIOD SEA) and } \\
\text { OECD STAN Database for Structural Analysis (ISIC Rev. 3)). }\end{array}$ \\
\hline GDP & Real GDP in logs Penn World Table 8.0 database (RGDPNA, 2005 PPP\$). \\
\hline GDP per capita & $\begin{array}{l}\text { Real GDP per capita in logs Penn World Table } 8.0 \text { database (RGDPCNA, } 2005 \\
\text { PPP\$). }\end{array}$ \\
\hline Population & Total population (Word Development Indicators, World Bank). \\
\hline Population 25-49 & $\begin{array}{l}\text { Percentage of total population by broad age group, both sexes per } 100 \text { total } \\
\text { population. (United Nations, Department of Economic and Social Affairs, } \\
\text { Population Division (2013). World Population Prospects: The } 2012 \text { Revision). }\end{array}$ \\
\hline National Elections & $\begin{array}{l}\text { A dummy variable taking the value of } 1 \text { in the presence of national (legislative or } \\
\text { presidential) election and } 0 \text { otherwise, and excluding early or snap elections. } \\
\text { Source: Wikipedia. }\end{array}$ \\
\hline Government Size & $\begin{array}{l}\text { Government consumption as a percentage of GDP at current PPPs (Penn World } \\
\text { Tables, Version 8.0). }\end{array}$ \\
\hline Natural Resources & Sum of Oil and Mineral Rents (World Development Indicators). \\
\hline Openness & Percentage of exports plus imports divided by Real GDP (World Penn Tables). \\
\hline Inequality & Gini coefficient based on net income inequality (Solt 2014). \\
\hline Fiscal Decentralization & $\begin{array}{l}\text { Fiscal autonomy of local governments measured by the extent that they are } \\
\text { independent from higher level funds, tax, expenditure and borrowing autonomy } \\
\text { (Ivanyna and Shah 2014). }\end{array}$ \\
\hline Political Decentralization & $\begin{array}{l}\text { Election of mayor and local council members and direct democracy provisions } \\
\text { for major tax, spending and regulatory decision and the recall of public officials } \\
\text { (Ivanyna and Shah 2014). }\end{array}$ \\
\hline Decentralization Index & $\begin{array}{l}\text { Fiscal and political decentralization plus information on the degree of } \\
\text { administrative autonomy and the security of existence of local governments } \\
\text { (Ivanyna and Shah 2014). }\end{array}$ \\
\hline Legal Origins & $\begin{array}{l}\text { Dummy variables that identify the legal origin of the company law or } \\
\text { commercial code of each country. There are five dummies: (1) English common } \\
\text { law; (2) French commercial code; (3) German commercial code; (4) } \\
\text { Scandinavian commercial code; (5) socialist communist laws (La Porta et al. } \\
\text { 1999). }\end{array}$ \\
\hline Religion & $\begin{array}{l}\text { Largest religions (Catholic, Protestants, Muslim and Eastern Orthodox) as a } \\
\text { percentage of population in } 2000 \text { (North et al. 2013). }\end{array}$ \\
\hline
\end{tabular}


Appendix C: Summary statistics

\begin{tabular}{|c|c|c|c|c|c|c|}
\hline & & Mean & $\begin{array}{l}\text { Standard } \\
\text { deviation }\end{array}$ & Minimum & Maximum & Observations \\
\hline \multirow{3}{*}{ Control of Corruption (WDI) } & Overall & 1.0824 & 0.9627 & -1.1339 & 2.5856 & $\mathrm{~N}=479$ \\
\hline & Between & & 0.9797 & -0.9182 & 2.4494 & $\mathrm{n}=42$ \\
\hline & Within & & 0.1610 & 0.2253 & 1.8143 & T-bar $=11.4048$ \\
\hline \multirow{3}{*}{ Construction } & Overall & 6.3201 & 1.6193 & 3.3935 & 12.1715 & $\mathrm{~N}=479$ \\
\hline & Between & & 1.3001 & 3.9888 & 9.9559 & $\mathrm{n}=42$ \\
\hline & Within & & 0.9919 & 2.5417 & 10.4132 & T-bar $=11.4048$ \\
\hline \multirow[t]{3}{*}{ Log of GDP*Construction } & Overall & 78.7840 & 21.1620 & 33.4387 & 168.8028 & $\mathrm{~N}=479$ \\
\hline & Between & & 17.4634 & 35.9099 & 138.5451 & $\mathrm{n}=42$ \\
\hline & Within & & 12.1866 & 38.1422 & 119.1916 & T-bar $=11.4048$ \\
\hline \multirow{3}{*}{$\begin{array}{l}\text { Population between } 25 \text { and } 49 \\
\text { years }\end{array}$} & Overall & 36.3164 & 1.878572 & 30.334 & 42.312 & $\mathrm{~N}=479$ \\
\hline & Between & & 1.759675 & 31.17833 & 41.72646 & $\mathrm{n}=42$ \\
\hline & Within & & .9172818 & 33.22331 & 40.172 & T-bar $=11.4048$ \\
\hline \multirow[t]{3}{*}{ National Elections } & Overall & 0.3069 & 0.4617 & 0 & 1 & $\mathrm{~N}=479$ \\
\hline & Between & & 0.1057 & 0.1538 & 0.5385 & $\mathrm{n}=42$ \\
\hline & Within & & 0.4497 & 0.2316 & 1 & T-bar $=11.4048$ \\
\hline \multirow[t]{3}{*}{ Log of GDP } & Overall & 12.5335 & 1.6923 & 8.8589 & 16.3977 & $\mathrm{~N}=479$ \\
\hline & Between & & 1.7331 & 9.0025 & 16.3486 & $\mathrm{n}=42$ \\
\hline & Within & & 0.1354 & 11.989 & 12.9787 & $\mathrm{~T}$-bar $=11.4048$ \\
\hline \multirow[t]{3}{*}{ Log of GDP per capita } & Overall & 9.9592 & 0.6667 & 7.4180 & 11.0484 & $\mathrm{~N}=479$ \\
\hline & Between & & 0.6727 & 7.7798 & 10.9679 & $\mathrm{n}=42$ \\
\hline & Within & & 0.1216 & 9.4034 & 10.3150 & T-bar $=11.4048$ \\
\hline \multirow{3}{*}{ Log of Population } & Overall & 2.5743 & 1.8129 & 1.2888 & 7.1104 & $\mathrm{~N}=479$ \\
\hline & Between & & 1.8765 & 1.2051 & 7.0209 & $\mathrm{n}=42$ \\
\hline & Within & & 0.0324 & 2.4435 & 2.6695 & $\mathrm{~T}-\mathrm{bar}=11.4048$ \\
\hline \multirow{3}{*}{ Public Sector Size } & Overall & 34.3938 & 13.0572 & 9.9236 & 99.000 & $\mathrm{~N}=479$ \\
\hline & Between & & 12.4831 & 12.3065 & 74.1870 & $\mathrm{n}=42$ \\
\hline & Within & & 5.8327 & 0.8256 & 68.9271 & T-bar $=11.4048$ \\
\hline \multirow[t]{3}{*}{ Natural Resources } & Overall & 1.3521 & 3.2090 & 0 & 19.9332 & $\mathrm{~N}=479$ \\
\hline & Between & & 3.3060 & 0 & 16.6884 & $\mathrm{n}=42$ \\
\hline & Within & & 0.6979 & 1.9322 & 4.8411 & T-bar $=11.4048$ \\
\hline \multirow[t]{3}{*}{ Openness } & Overall & 92.5818 & 50.4575 & 15.8650 & 333.5322 & $\mathrm{~N}=479$ \\
\hline & Between & & 50.9919 & 24.5443 & 295.4356 & $\mathrm{n}=42$ \\
\hline & Within & & 10.6794 & 45.7050 & 130.6784 & T-bar $=11.4048$ \\
\hline \multirow[t]{3}{*}{ Inequality } & Overall & 31.5879 & 6.2676 & 20.7933 & 53.2056 & $\mathrm{~N}=479$ \\
\hline & Between & & 6.5437 & 23.5389 & 49.5488 & $\mathrm{n}=42$ \\
\hline & Within & & 1.3584 & 26.0799 & 36.1348 & T-bar $=11.4048$ \\
\hline \multirow[t]{2}{*}{ Fiscal Decentralization } & Overall & 0.5970 & 0.2149 & 0.1000 & 0.9600 & $\mathrm{~N}=479$ \\
\hline & Between & & 0.2178 & 0.1000 & 0.9600 & $\mathrm{n}=42$ \\
\hline \multirow{3}{*}{ Political Decentralization } & $\begin{array}{l}\text { Within } \\
\text { Overall }\end{array}$ & 0.6821 & 0.1313 & 0.4200 & 1 & $\begin{array}{c}\mathrm{T}=1 \\
\mathrm{~N}=479\end{array}$ \\
\hline & Between & & 0.1378 & 0.4200 & 1 & $\mathrm{n}=42$ \\
\hline & Within & & & & & T-bar $=11.4048$ \\
\hline
\end{tabular}




\section{References}

Ades, A., \& Di Tella, R. (1999). Rents, competition and corruption. American Economic Review, 89(4), 982-993.

ASCE. (2004). Civil engineers call for global standards to curb trillion dollar worldwide corruption. http://asce.org/pressroom/news/displaypress.cfm?uid_1711__Sept. 30. Accessed 01 January 2015.

Aslaksen, S. (2009). Corruption and oil: evidence from panel data. Mimeo (Working Paper). http://www.sv.uio.no/econ/personer/vit/siljeasl/corruption.pdf. Accessed 01 February 2015.

Bäck, H., \& Hadenius, A. (2008). Democracy and state capacity: exploring a j-shaped relationship. Governance, 21(1), 1-24.

Baltagi, B. (2013). Econometric analysis of panel data. $5^{\text {th }}$ Edition. Wiley.

Buchanan, J. (1980). Rent seeking and profit seeking. In J. Buchanan, R. Tollison, G. Tullock (Eds.), Towards a theory of the rent-seeking society (pp. 3-15). College Station: Texas A\&M University Press.

Bulte, E., Damania, R., \& Deacon R. (2005). Resource intensity, institutions, and development. World Development, 33(7), 1029-1044

Busse, M., \& Gröning, S. (2013). The resource curse revisited: governance and natural resources. Public Choice, 154(1-2), 1-20.

Brender, A., \& Drazen, A. (2005). Political budget cycles in new versus established democracies. Journal of Monetary Economics 52, 1271-1295. 
Charron, N. (2015). Do corruption measures have a perception problem? Assessing the relationship between experiences and perceptions of corruption among citizens and experts. European Political Science Review. DOI: 10.1017/S1755773914000447.

Djankov, S., La Porta, R., Lopez de-Silanes, F., \& Shleifer, A. (2002). The regulation of entry. Quarterly Journal of Economics, 117(1): 1-37.

Dwight, J., Rosen, K., Friedman, B., \& Klein, L. (1979). Mortgage credit availability and residential construction. Brookings Papers on Economic Activity, 1979 (2), 333-386.

Escaleras, M., Anbarci, N., \& Register, C. (2007). Public sector corruption and major earthquakes: a potentially deadly interaction. Public Choice, 132(1) 209-230.

European Commission. (2013). Industrial policy indicators analysis. December, Brussels.

European Commission. (2014). High level tripartite strategic forum report on follow-up actions on the communication and action plan Construction 2020. February, Brussels.

Fisman, R., \& Miguel, E. (2007). Corruption, norms, and legal enforcement: evidence from diplomatic parking tickets. Journal of Political Economy, 115(6), 10201048

Guiso, L., Sapienza, P., \& Zingales, L. (2003). People's opium? religion and economic attitudes. Journal of Monetary Economics, 50, 225-82. 
Gupta, S., Davoodi, H., \& Alonso-Terme, R. (2002). Does corruption affect income inequality and poverty? Economics of Governance, 3, 23-45.

Gupta, S., Davoodi, H., Tiongson, E. (2001). Corruption and the provision of healthcare and education services. In A. Jain (Ed.), The political economy of corruption (pp. 111-41), London: Routledge.

Gupta, S., de Mello, L. \& Sharan, R. (2001). Corruption and military spending. European Journal of Political Economy, 17(4), 749-77.

Hardoon D., \& Heinrich F. (2011). Bribe payers index. Transparency International

Hessami, Z. (2014). Political corruption, public procurement, and budget composition: Theory and evidence from OECD countries. European Journal of Political Economy, 34, 372-389.

Heywood, P. (2015). Measuring corruption. Perspectives, critiques and limits. In P. Heywood (Ed.), Routledge handbook of political corruption (pp. 137-153). . London and New York: Routledge.

Imbs, J., \& Wacziarg, R. (2003). Stages of diversification. American Economic Review, 93(1), 63-86.

Isham, J., Woolcock, M., Pritchett, L., \& Busby, G. (2005). The varieties of resource experience: natural resource export structures and the political economy of economic growth, The World Bank Economic Review, 19(2): 141-174.

Ivanyna, M., \& Shah, A. (2014). How close is your government to its people? Worldwide indicators on localization and decentralization. Economics: The Open-Access, Open-Assessment E-Journal, 8(3): 1-61. 
Jensen, N., \& Rahman, A. (2015). The silence of corruption. Identifying underreporting of business corruption through randomized response techniques. In P. Heywood (Ed.), Routledge handbook of political corruption (pp 154-171). London and New York: Routledge.

Jimenez, F. (2009). Building boom and political corruption in Spain. South European Society and Politics, 14(3), 255-272.

Johnson, S., Kaufmann, D., \& Zoido-Lobaton, P. (1998). Regulatory discretion and the unofficial economy. American Economic Review, Papers and Proceedings, 88, 387-92.

Jong, D., Henry, P., \& Stansbury, N. (2009). Eliminating corruption in our engineering/construction industry. Leadership and Management in Engineering, $9,105-111$.

Kaufmann, D., Kraay, A., \& Mastrutzzi, M. (2010). The worldwide governance indicators: methodology and analytical issues. World Bank Policy Research Paper 5430.

Kenny, C. (2006). Measuring and reducing the impact of corruption in infrastructure. World Bank Policy Research Working Paper 4099.

Kenny, C. (2009). Transport construction, corruption and developing countries. Transport Reviews: A Transnational Transdisciplinary Journal, 29(1), 21-41.

Knack, S., \& Azfar, O. (2003). Trade intensity, country size and corruption. Economics of Governance, 4, 1-18. 
Knack, S., \& Keefer, P. (1995). Institutions and economic performance: cross-country tests using alternative institutional measures. Economics and Politics, 7, 207-27.

Kyriacou, A., \& Roca-Sagalés, O. (2011a). Fiscal decentralization and government quality in the OECD. Economics Letters, 111, 191-193.

Kyriacou, A., \& Roca-Sagalés, O. (2011b). Fiscal and political decentralization and government quality. Environment and Planning C (Government and Policy), 29, 204-223.

Lamsdorff, J. (2002). Corruption and rent-seeking. Public Choice (1-2), 113: 97-125.

La Porta, R., Lopez-de-Silanes, F., Shleifer, A., \& Vishny, R. (1999). The quality of government. Journal of Law, Economics, and Organization, 15(1), 222-79.

Leite, C., \& Weidmann, J. (2002). Does mother nature corrupt? Natural resources, corruption and economic growth. In G. Abed, S. Gupta (Eds.), Governance, Corruption and Economic Performance (pp. 159-196). Washington, DC: IMF.

Le Y., Shan M., Chan A., \& Yi H. (2014). Overview of corruption research in construction. Journal of Management in Engineering, 30(4): 1-7.

Lindh T., \& Malberg B. (2008). Demography and housing demand - what can we learn from residential construction data. Journal of Population Economics, 21, 521539.

Liu C., \& Mikesell J. (2014). The impact of public officials' corruption on the size and allocation of U.S. State spending. Public Administration Review, 74(3): 346359. 
Mankiw, G., \& Weil, D. (1989). The baby boom, the baby bust, and the housing market. Regional Science and Urban Economics, 19, 235-258.

Mauro, P. (1997). The effects of corruption on growth, investment, and government expenditure: a cross-country analysis. In K. Elliott (Ed.), Corruption and the global economy pp. 83-107. Washington, DC: Institute for International Economics.

Mauro, P. (1998). Corruption and the composition of government expenditure. Journal of Public Economics, 69, 263-79.

McChesney, F. (1997). Money for Nothing. Politicians, rent extraction and political extortion. Cambridge MA: Harvard University Press.

North, C., Orman, W., \& Gwin, C. (2013). Religion, corruption, and the rule of law. Journal of Money, Credit and Banking, 45 (5), 757-779.

OECD. (2008). Competition in the construction industry. OECD Policy Roundtables. DAF/COMP 36. Paris: OECD.

OECD. (2014). Foreign bribery report. An analysis of the crime of bribery of foreign public officials. DOI: 10.1787/9789264226616-en.

Pellegrini, L., \& Gerlagh, R. (2004). Corruption's effect on growth and its transmission channels, Kyklos 57, 429-456.

Persson, T., Tabellini, G., \& Trebbi. F. (2003). Electoral rules and corruption. Journal of European Economic Association, 1(4), 958 - 989.

Sala-i-Martin, X., \& Subramanian, A. (2013). Addressing the natural resource curse: an illustration from Nigeria, Journal of African Economies, 22(4), 570-615. 
Schneider, F., Buehn, A., \& Montenegro, C. (2010). Shadow economies all over the world: new estimates for 162 countries from 1999 to 2007. World Bank Policy Research Paper 5356. Washington DC: The World Bank.

Shleifer A., \& Vishny R. (1993). Corruption. Quarterly Journal of Economics, 108, 599 $-616$.

Sohail, M., \& Cavill, S. (2008). Accountability to prevent corruption in construction projects. Journal of Construction Engineering and Management, 134(9), 729738.

Staiger, D., \& Stock, J. (1997). Instrumental variables regression with weak instruments. Econometrica, 65, 557-586.

Stock, J., \& Yogo M. (2005). Testing for weak instruments in linear IV regression. In A. Donald, J. Stock (Eds.), Identification and inference for econometric models: Essays in honor of Thomas Rothenberg (pp. 80-108). Cambridge: Cambridge University Press.

Svensson, J. (2005). Eight questions about corruption. Journal of Economic Perspectives, 19(3): 19-42.

Tanzi, V. (1998). Corruption around the world. Causes, consequences, scope, and cures. IMF Staff Papers, 45, 559-594.

Tanzi, V., \& Davoodi, H. (1997). Corruption, public investment, and growth. International Monetary Fund Working Paper, 97/139.

Tanzi, V., \& Davoodi, H. (2001). Corruption, growth, and public finances. In A. Jain (Ed.), Political economy of corruption (pp. 89-110). London: Routledge,. 
Timmer, M., Dietzenbacher, E., Los, B., Stehrer., R. \& de Vries, G. (2015). An illustrated user guide to the world input-output database: The case of global automotive production. Review of International Economics (in press).

Treisman, D. (2000.) The causes of corruption: a cross-national study. Journal of Public Economics, 76, 399-457.

Treisman, D. (2002). Decentralization and the quality of government. Mimeo: University of California.

Treisman, D. (2015). What does cross-national empirical research reveal about the causes of corruption? In P. Heywood (Ed.), Routledge handbook of political corruption (pp. 95-109). London and New York: Routledge.

Tullock, G. (1967). The welfare costs of tariffs, monopolies and theft. Western Economic Journal 5(3), 224-32.

Uslaner, E. (2010). Corruption, inequality and the rule of law. Cambridge University Press.

Wilhemsson, M., \& Wigren, R. (2011). The robustness of the causal and economic relationship between construction flows and economic growth: evidence from Western Europe. Applied Economics, 43(7), 891-900.

Wollmann, H. (2008). Comparing local government reforms in England, Sweden, France andcGermany. Between continuity and change, divergence and convergence. www.wuestenrotstiftung.de/download/local-government.

You, J., \& Khagram, S. (2005). A comparative study of inequality and corruption. American Sociological Review, 70, 136-157. 
Figures and tables to be embedded in the text

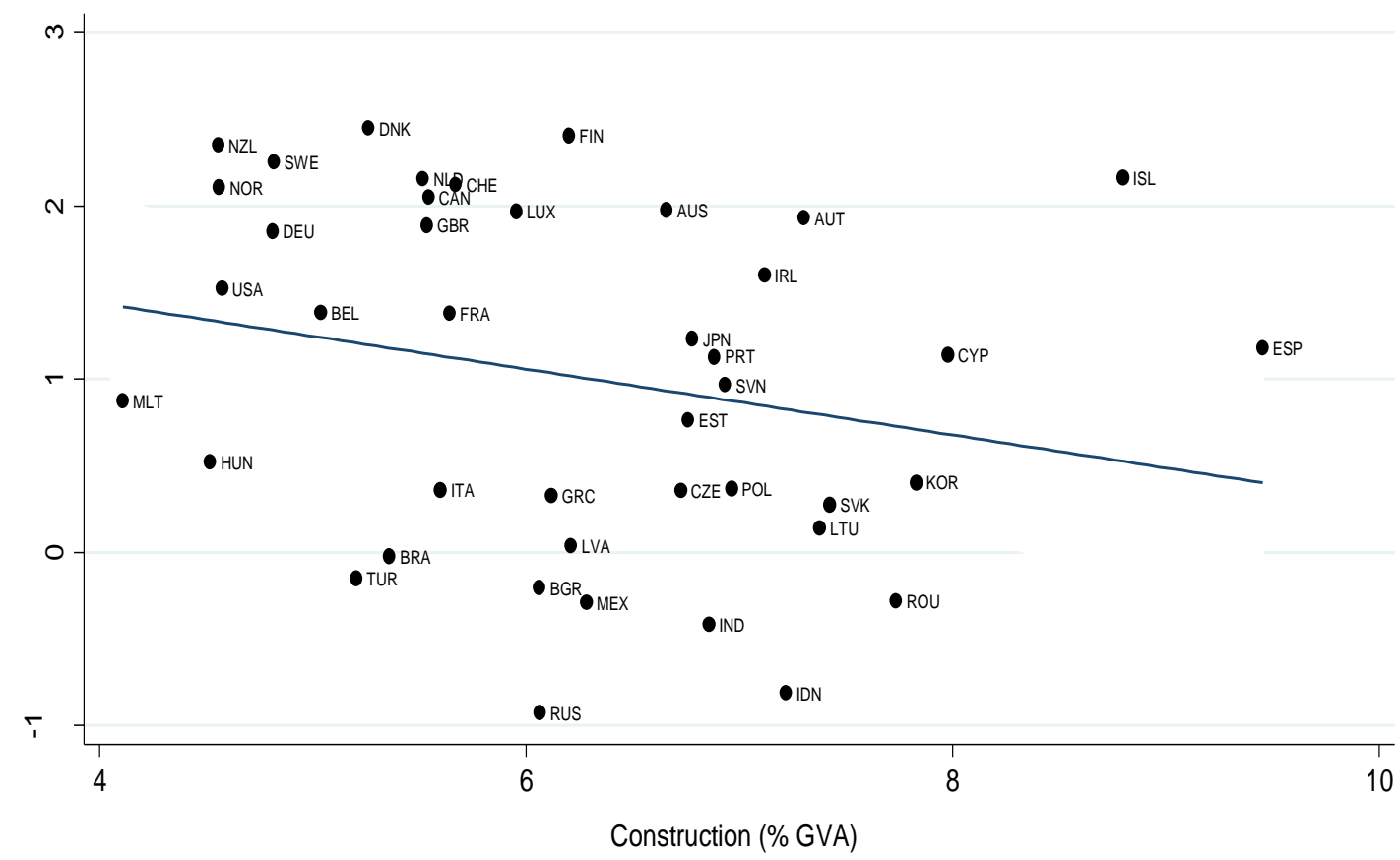

Fig. 1 Control of corruption and construction as a percentage of GVA (average values over the period 1995-2011)

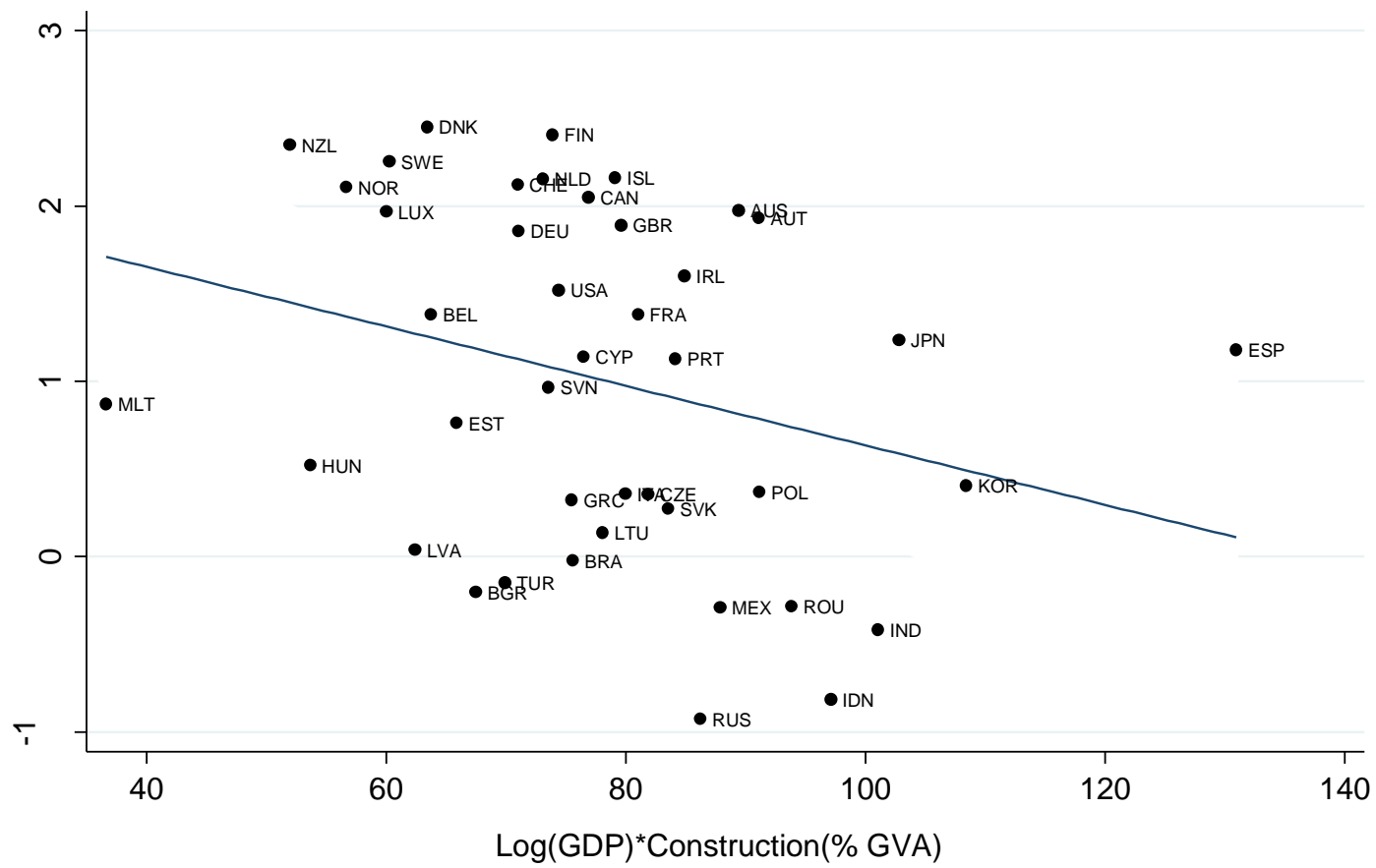

Fig. 2 Control of corruption and construction sector volume (average values over the period 1995-2011) 
Table 1 The impact of construction on control of corruption

\begin{tabular}{|c|c|c|c|c|c|c|}
\hline & $\begin{array}{l}\text { (1) } \\
\text { OLS }\end{array}$ & $\begin{array}{l}\text { (2) } \\
\text { TSLS }\end{array}$ & $\begin{array}{l}\text { (3) } \\
\text { TSLS }\end{array}$ & $\begin{array}{l}\text { (4) } \\
\text { OLS }\end{array}$ & $\begin{array}{l}\text { (5) } \\
\text { TSLS }\end{array}$ & $\begin{array}{l}\text { (6) } \\
\text { TSLS }\end{array}$ \\
\hline \multicolumn{7}{|c|}{ Panel A. Second stage: Dependent variable is Control of Corruption } \\
\hline Construction (\% GVA) & $\begin{array}{l}-0.048 * \\
(0.026)\end{array}$ & $\begin{array}{l}-0.173 * * \\
(0.072)\end{array}$ & $\begin{array}{l}-0.059 * * \\
(0.029)\end{array}$ & -- & -- & -- \\
\hline (Log of GDP) ${ }^{*}$ Construction & -- & -- & -- & $\begin{array}{l}-0.004 * * \\
(0.002)\end{array}$ & $\begin{array}{l}-0.014 * * \\
(0.006)\end{array}$ & $\begin{array}{l}-0.005 * * \\
(0.002)\end{array}$ \\
\hline Log of GDP per Capita & $\begin{array}{l}0.670 * * * \\
(0.115)\end{array}$ & $\begin{array}{l}0.649 * * * \\
(0.118)\end{array}$ & $\begin{array}{l}0.669 * * * \\
(0.114)\end{array}$ & $\begin{array}{l}0.689 * * * \\
(0.116)\end{array}$ & $\begin{array}{l}0.713 * * * \\
(0.117)\end{array}$ & $\begin{array}{l}0.691 * * * \\
(0.115)\end{array}$ \\
\hline Log of Population & $\begin{array}{l}-0.094 * * \\
(0.047)\end{array}$ & $\begin{array}{l}-0.148 * * * \\
(0.055)\end{array}$ & $\begin{array}{l}-0.098 * * \\
(0.047)\end{array}$ & $\begin{array}{l}-0.069 \\
(0.046)\end{array}$ & $\begin{array}{l}-0.060 \\
(0.047)\end{array}$ & $\begin{array}{l}-0.069 \\
(0.045)\end{array}$ \\
\hline Public Sector Size (\% GDP) & $\begin{array}{l}-0.000 \\
(0.004)\end{array}$ & $\begin{array}{l}-0.005 \\
(0.005)\end{array}$ & $\begin{array}{l}-0.001 \\
(0.004)\end{array}$ & $\begin{array}{l}-0.000 \\
(0.004)\end{array}$ & $\begin{array}{l}-0.005 \\
(0.005)\end{array}$ & $\begin{array}{l}-0.001 \\
(0.004)\end{array}$ \\
\hline Natural Resources (\% GDP) & $\begin{array}{l}-0.039 * * * \\
(0.016)\end{array}$ & $\begin{array}{l}-0.051^{* * *} \\
(0.018)\end{array}$ & $\begin{array}{l}-0.040 * * \\
(0.016)\end{array}$ & $\begin{array}{l}-0.038 * * * \\
(0.016)\end{array}$ & $\begin{array}{l}-0.049 * * * \\
(0.017)\end{array}$ & $\begin{array}{l}-0.039 * * \\
(0.016)\end{array}$ \\
\hline Openness (\% GDP) & $\begin{array}{l}-0.001 \\
(0.001)\end{array}$ & $\begin{array}{l}-0.003^{*} \\
(0.002)\end{array}$ & $\begin{array}{l}-0.001 \\
(0.001)\end{array}$ & $\begin{array}{l}-0.001 \\
(0.001)\end{array}$ & $\begin{array}{l}-0.003 \\
(0.002)\end{array}$ & $\begin{array}{l}-0.001 \\
(0.001)\end{array}$ \\
\hline Inequality & $\begin{array}{l}-0.012 \\
(0.013)\end{array}$ & $\begin{array}{l}-0.012 \\
(0.014)\end{array}$ & $\begin{array}{l}-0.012 \\
(0.013)\end{array}$ & $\begin{array}{l}-0.012 \\
(0.013)\end{array}$ & $\begin{array}{l}-0.013 \\
(0.013)\end{array}$ & $\begin{array}{l}-0.013 \\
(0.013)\end{array}$ \\
\hline Fiscal Decentralization & $\begin{array}{l}0.824 * * * \\
(0.302)\end{array}$ & $\begin{array}{l}0.722 * * \\
(0.310)\end{array}$ & $\begin{array}{l}0.816^{* * * *} \\
(0.300)\end{array}$ & $\begin{array}{l}0.829 * * * \\
(0.301)\end{array}$ & $\begin{array}{l}0.747 * * \\
(0.308)\end{array}$ & $\begin{array}{l}0.822 * * * \\
(0.299)\end{array}$ \\
\hline Political Decentralization & $\begin{array}{l}-1.207 * * * \\
(0.446)\end{array}$ & $\begin{array}{l}-1.592 * * * \\
(0.506)\end{array}$ & $\begin{array}{l}-1.239 * * * \\
(0.445)\end{array}$ & $\begin{array}{l}-1.243^{* * * *} \\
(0.448)\end{array}$ & $\begin{array}{l}-1.674 * * * \\
(0.520)\end{array}$ & $\begin{array}{l}-1.279 * * * \\
(0.447)\end{array}$ \\
\hline Legal French & $\begin{array}{l}-0.668 * * * \\
(0.142)\end{array}$ & $\begin{array}{l}-0.687 * * * \\
(0.145)\end{array}$ & $\begin{array}{l}-0.670^{* * *} \\
(0.141)\end{array}$ & $\begin{array}{l}-0.664 * * * \\
(0.141)\end{array}$ & $\begin{array}{l}-0.672 * * * \\
(0.143)\end{array}$ & $\begin{array}{l}-0.665 * * * \\
(0.141)\end{array}$ \\
\hline Legal German & $\begin{array}{l}-0.322 * \\
(0.195)\end{array}$ & $\begin{array}{l}-0.328 * \\
(0.198)\end{array}$ & $\begin{array}{l}-0.323^{*} \\
(0.193)\end{array}$ & $\begin{array}{l}-0.318^{*} \\
(0.194)\end{array}$ & $\begin{array}{l}-0.314 \\
(0.197)\end{array}$ & $\begin{array}{l}-0.318 \\
(0.193)\end{array}$ \\
\hline Legal Scandinavian & $\begin{array}{l}-0.074 \\
(0.227)\end{array}$ & $\begin{array}{l}-0.210 \\
(0.245)\end{array}$ & $\begin{array}{l}-0.085 \\
(0.227)\end{array}$ & $\begin{array}{l}-0.083 \\
(0.227)\end{array}$ & $\begin{array}{l}-0.227 \\
(0.247)\end{array}$ & $\begin{array}{l}-0.095 \\
(0.226)\end{array}$ \\
\hline Legal Soviet & $\begin{array}{l}-1.025^{* * *} \\
(0.173)\end{array}$ & $\begin{array}{l}-1.023^{* * *} \\
(0.177)\end{array}$ & $\begin{array}{l}-1.025^{* * *} \\
(0.172)\end{array}$ & $\begin{array}{l}-1.030 * * * \\
(0.172)\end{array}$ & $\begin{array}{l}-1.040 * * * \\
(0.176)\end{array}$ & $\begin{array}{l}-1.031 * * * \\
(0.171)\end{array}$ \\
\hline Adjusted $R^{2}$ & 0.869 & 0.835 & 0.868 & 0.869 & 0.839 & 0.869 \\
\hline \multicolumn{7}{|c|}{ Panel B. First stage: Dependent variable is Construction } \\
\hline Population 25-49 & & $\begin{array}{l}0.353 * * * \\
(0.082)\end{array}$ & & & $\begin{array}{l}4.530 * * * \\
(1.030)\end{array}$ & \\
\hline National Elections & & $\begin{array}{l}0.296^{* * * *} \\
(0.084)\end{array}$ & & & $\begin{array}{l}3.568 * * * \\
(1.029)\end{array}$ & \\
\hline Construction (lagged) & & & $\begin{array}{l}0.928 * * * \\
(0.021)\end{array}$ & & & $\begin{array}{l}0.939 * * * \\
(0.020)\end{array}$ \\
\hline Adjusted $R^{2}$ & & 0.357 & 0.888 & & 0.433 & 0.912 \\
\hline$F$-statistic from first stage & & 11.227 & 153.22 & & 15.057 & 200.08 \\
\hline Observations & 479 & 479 & 479 & 479 & 479 & 479 \\
\hline
\end{tabular}

Notes: $* * * \mathrm{p}<0.01, * * \mathrm{p}<0.05, * \mathrm{p}<0.1$. All regressions report Period SUR panel corrected standard errors and include period fixed effects. Construction is instrumented using both the percentage of population between 25 and 49 years old and a dummy accounting for national elections (regressions 2 and 5) and employing 1-year lagged values of the corresponding construction indicator (regressions 3 and 6). All regressions include a constant and the full set of control variables (not shown in the panel B). 
Table 2 The impact of construction on control of corruption (TSLS)

\begin{tabular}{|c|c|c|c|c|c|c|}
\hline & $\begin{array}{c}\text { (1) } \\
\text { Two lags }\end{array}$ & $\begin{array}{c}\text { (2) } \\
\text { Three lag }\end{array}$ & $\begin{array}{c}\text { (3) } \\
\text { Four lags }\end{array}$ & $\begin{array}{c}\text { (4) } \\
\text { Two lags }\end{array}$ & $\begin{array}{c}(5) \\
\text { Three lags }\end{array}$ & $\begin{array}{c}(6) \\
\text { Four lags }\end{array}$ \\
\hline \multicolumn{7}{|c|}{ Panel A. Second stage: Dependent variable is Control of Corruption } \\
\hline Construction ( $\%$ GVA) & $\begin{array}{l}-0.076^{* *} \\
(0.034)\end{array}$ & $\begin{array}{l}-0.094 * * \\
(0.041)\end{array}$ & $\begin{array}{l}-0.120 * * \\
(0.051)\end{array}$ & -- & -- & -- \\
\hline$(\log$ of GDP) $*$ Construction & -- & -- & -- & $\begin{array}{l}-0.006^{* *} \\
(0.003)\end{array}$ & $\begin{array}{l}-0.007 * * \\
(0.003)\end{array}$ & $\begin{array}{l}-0.009 * * \\
(0.004)\end{array}$ \\
\hline Log of GDP per Capita & $\begin{array}{l}0.663 * * * \\
(0.114)\end{array}$ & $\begin{array}{l}0.659 * * * \\
(0.114)\end{array}$ & $\begin{array}{l}0.645 * * * \\
(0.118)\end{array}$ & $\begin{array}{l}0.691 * * * \\
(0.115)\end{array}$ & $\begin{array}{l}0.694 * * * \\
(0.114)\end{array}$ & $\begin{array}{l}0.686 * * * \\
(0.118)\end{array}$ \\
\hline Log of Population & $\begin{array}{l}-0.111^{* *} \\
(0.047)\end{array}$ & $\begin{array}{l}-0.118 * * \\
(0.047)\end{array}$ & $\begin{array}{l}-0.130 * * * \\
(0.049)\end{array}$ & $\begin{array}{l}-0.072 \\
(0.045)\end{array}$ & $\begin{array}{l}-0.070 \\
(0.045)\end{array}$ & $\begin{array}{l}-0.070 \\
(0.046)\end{array}$ \\
\hline Public Sector Size (\% GDP) & $\begin{array}{l}-0.002 \\
(0.004)\end{array}$ & $\begin{array}{l}-0.003 \\
(0.004)\end{array}$ & $\begin{array}{l}-0.004 \\
(0.005)\end{array}$ & $\begin{array}{l}-0.002 \\
(0.004)\end{array}$ & $\begin{array}{l}-0.002 \\
(0.004)\end{array}$ & $\begin{array}{l}-0.004 \\
(0.004)\end{array}$ \\
\hline Natural Resources (\% GDP) & $\begin{array}{l}-0.042 * * * \\
(0.016)\end{array}$ & $\begin{array}{l}-0.044 * * * \\
(0.016)\end{array}$ & $\begin{array}{l}-0.047 * * * \\
(0.017)\end{array}$ & $\begin{array}{l}-0.042 * * * \\
(0.016)\end{array}$ & $\begin{array}{l}-0.043 * * * \\
(0.016)\end{array}$ & $\begin{array}{l}-0.045^{* * *} \\
(0.016)\end{array}$ \\
\hline Openness (\% GDP) & $\begin{array}{l}-0.002 \\
(0.001)\end{array}$ & $\begin{array}{l}-0.002 \\
(0.001)\end{array}$ & $\begin{array}{l}-0.002 \\
(0.002)\end{array}$ & $\begin{array}{l}-0.002 \\
(0.001)\end{array}$ & $\begin{array}{l}-0.002 \\
(0.002)\end{array}$ & $\begin{array}{l}-0.002 \\
(0.001)\end{array}$ \\
\hline Inequality & $\begin{array}{l}-0.010 \\
(0.013)\end{array}$ & $\begin{array}{l}-0.010 \\
(0.013)\end{array}$ & $\begin{array}{l}-0.010 \\
(0.014)\end{array}$ & $\begin{array}{l}-0.011 \\
(0.013)\end{array}$ & $\begin{array}{l}-0.011 \\
(0.013)\end{array}$ & $\begin{array}{l}-0.010 \\
(0.013)\end{array}$ \\
\hline Fiscal Decentralization & $\begin{array}{l}0.823 * * * \\
(0.298)\end{array}$ & $\begin{array}{l}0.807 * * * \\
(0.298)\end{array}$ & $\begin{array}{l}0.802 * * * \\
(0.305)\end{array}$ & $\begin{array}{l}0.834 * * * \\
(0.298)\end{array}$ & $\begin{array}{l}0.822 * * * \\
(0.297)\end{array}$ & $\begin{array}{l}0.826 * * * \\
(0.303)\end{array}$ \\
\hline Political Decentralization & $\begin{array}{l}-1.330 * * * \\
(0.446)\end{array}$ & $\begin{array}{l}-1.386 * * * \\
(0.449)\end{array}$ & $\begin{array}{l}-1.472 * * * \\
(0.463)\end{array}$ & $\begin{array}{l}-1.371 * * * \\
(0.449)\end{array}$ & $\begin{array}{l}-1.428 * * * \\
(0.453)\end{array}$ & $\begin{array}{l}-1.517 * * * \\
(0.467)\end{array}$ \\
\hline Legal French & $\begin{array}{l}-0.658^{* * * *} \\
(0.142)\end{array}$ & $\begin{array}{l}-0.660^{* * *} \\
(0.141)\end{array}$ & $\begin{array}{l}-0.663^{* * *} \\
(0.145)\end{array}$ & $\begin{array}{l}-0.653 * * * \\
(0.141)\end{array}$ & $\begin{array}{l}-0.653^{* * *} \\
(0.141)\end{array}$ & $\begin{array}{l}-0.654 * * * \\
(0.144)\end{array}$ \\
\hline Legal German & $\begin{array}{l}-0.307 \\
(0.192)\end{array}$ & $\begin{array}{l}-0.310 \\
(0.191)\end{array}$ & $\begin{array}{l}-0.318 \\
(0.195)\end{array}$ & $\begin{array}{l}-0.301 \\
(0.192)\end{array}$ & $\begin{array}{l}-0.304 \\
(0.191)\end{array}$ & $\begin{array}{l}-0.308 \\
(0.194)\end{array}$ \\
\hline Legal Scandinavian & $\begin{array}{l}-0.087 \\
(0.226)\end{array}$ & $\begin{array}{l}-0.106 \\
(0.227)\end{array}$ & $\begin{array}{l}-0.110 \\
(0.233)\end{array}$ & $\begin{array}{l}-0.097 \\
(0.227)\end{array}$ & $\begin{array}{l}-0.115 \\
(0.227)\end{array}$ & $\begin{array}{l}-0.121 \\
(0.233)\end{array}$ \\
\hline Legal Soviet & $\begin{array}{l}-1.002^{* * *} \\
(0.171)\end{array}$ & $\begin{array}{l}-1.001 * * * \\
(0.171)\end{array}$ & $\begin{array}{l}-1.005^{* * *} \\
(0.174)\end{array}$ & $\begin{array}{l}-1.011 * * * \\
(0.171)\end{array}$ & $\begin{array}{l}-1.012 * * * \\
(0.170)\end{array}$ & $\begin{array}{l}-1.021 * * * \\
(0.173)\end{array}$ \\
\hline Adjusted $R^{2}$ & 0.872 & 0.869 & 0.864 & 0.872 & 0.870 & 0.867 \\
\hline \multicolumn{7}{|c|}{ Panel B. First stage: Dependent variable is Construction } \\
\hline Construction (lagged) & $\begin{array}{l}0.805 * * * \\
(0.043)\end{array}$ & $\begin{array}{l}0.693 * * * \\
(0.059)\end{array}$ & $\begin{array}{l}0.613 * * * \\
(0.076)\end{array}$ & $\begin{array}{l}0.837 * * * \\
(0.040)\end{array}$ & $\begin{array}{l}0.742 * * * \\
(0.057)\end{array}$ & $\begin{array}{l}0.671 * * * \\
(0.074)\end{array}$ \\
\hline Adjusted $R^{2}$ & 0.730 & 0.596 & 0.505 & 0.787 & 0.674 & 0.591 \\
\hline$F$-statistic from first stage & 51.887 & 28.832 & 19.830 & 70.467 & 39.893 & 27.669 \\
\hline Observations & 453 & 453 & 425 & 453 & 453 & 425 \\
\hline
\end{tabular}

Notes: $* * * \mathrm{p}<0.01, * * \mathrm{p}<0.05, * \mathrm{p}<0.1$. All regressions report Period SUR panel corrected standard errors and include period fixed effects. Construction is instrumented using 2, 3 and 4-year lagged values of the corresponding construction indicator. All regressions include a constant and the full set of control variables (not shown in the panel B). 
Table 3 Robustness analysis (TSLS)

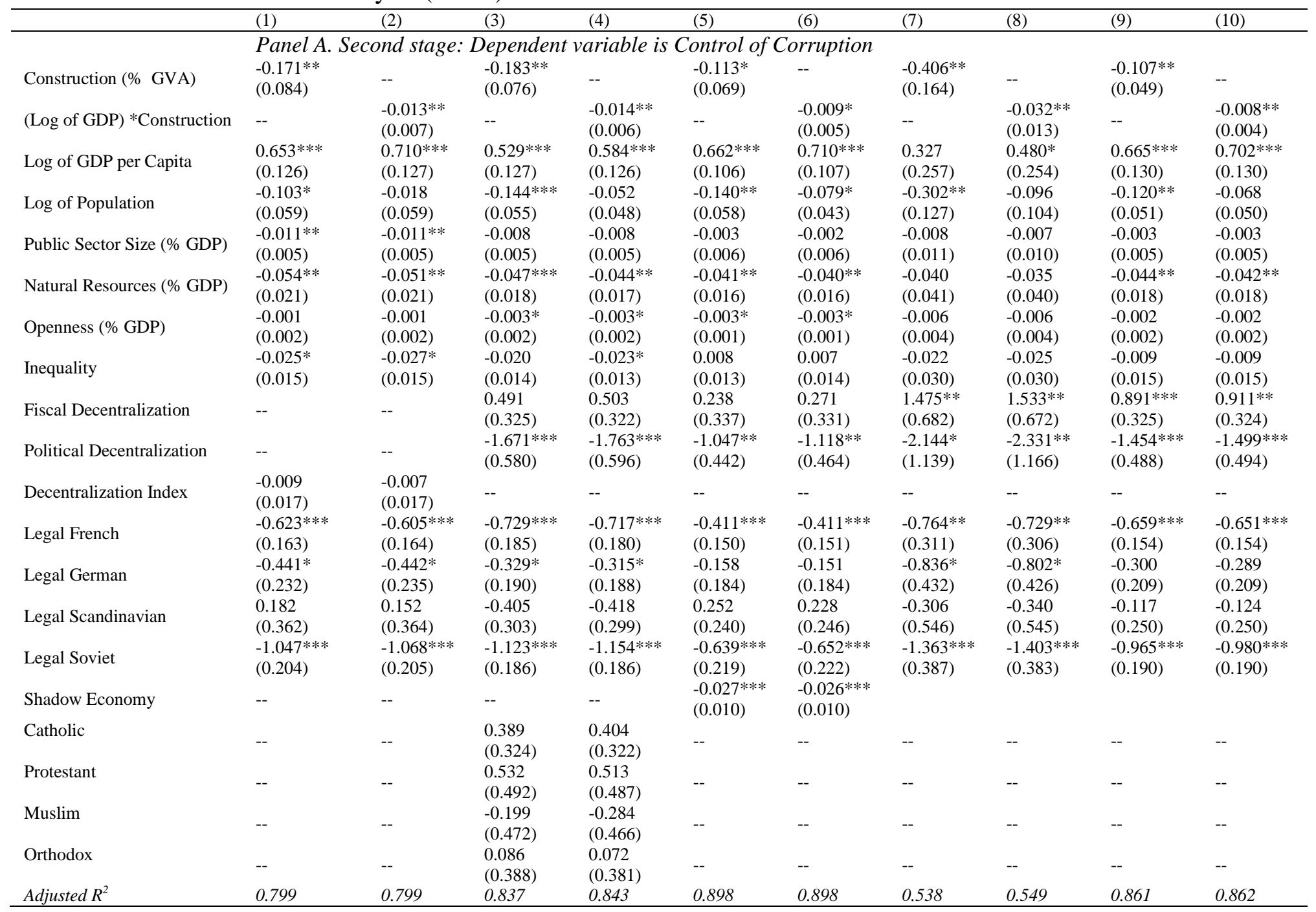




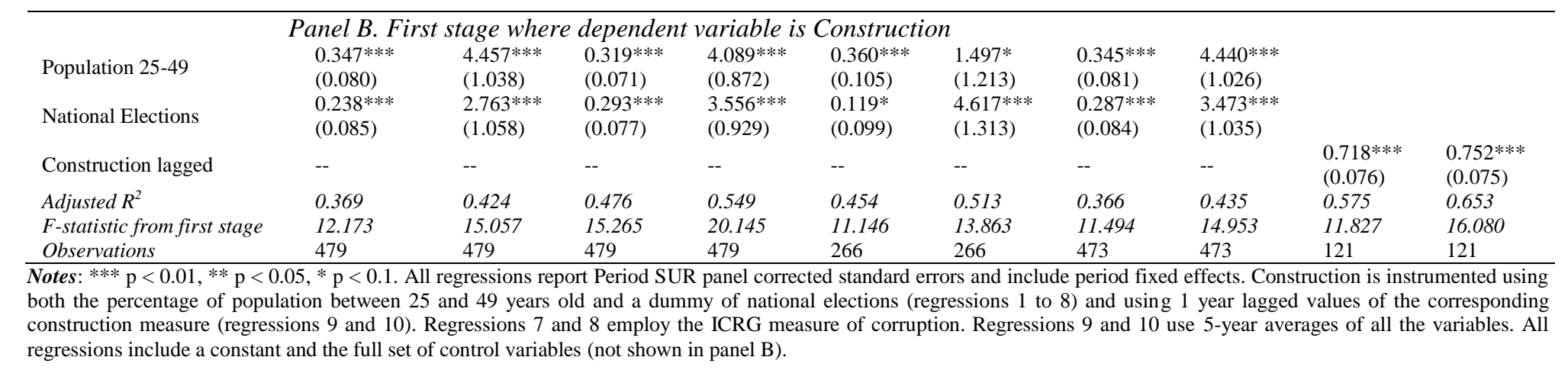

